\section{From Nemesis Island}

Christine Mustchin. Leicester, UK: Matador (Troubador Publishing Ltd), 2010. ISBN-13: 978-1-84876-406-4. Price: f7.99. Pages: 328 (paperback)

An anonymous Adriatic island, a London journalist called Richard and his girlfriend Trish, a PR and marketing executive, are the main players in this fiction book, From Nemesis Island, by new author, Christine Mustchin.

The book opens to a prologue that sets our scene with a picture of struggling, cruelty, escape and healing, themes which are replayed throughout the rest of the novel. This is in stark contrast to the opening of the first chapter where we are introduced to Richard, the journalist, sitting in a cafe, in a beautiful undiscovered part of the Adriatic coast. His job is to visit an educational establishment on a nearby island. He has the glossy brochure in front of him and is bored. He fears that this will be a rubber-stamping exercise and does not know why he was sent on the assignment.

Back in London, Trish is at a party with some friends where they are discussing the concepts of 'girl power' and the exploitation of sexuality to achieve independence and autonomy. The conversation moves on to include prostitution, illegal immigration and young girls who have no choices and who end up physically abused due to cultural practices. Trish has been approached professionally by a cosmetic surgeon who practises abroad and wishes to promote his business in the UK, so when David, a local general practitioner and friend, broadens the conversation with a medical slant, she is unusually interested. He explains that he works in a special clinic and sees examples of female circumcision. Trish asks him to explain more and is both fascinated and horrified by his descriptions.

Over the next few chapters, we learn more about the island and how Richard and Trish are drawn into a world of sexual abuse and well-organised prostitution. Sex is an important and enjoyable part in Richard and Trish's relationship and their thoughts and feelings are challenged by the people they meet and their life-changing experiences.

Some areas of this book are very graphic and personally I would have welcomed less description but that is the whole point of this book. In sexual and reproductive health we are privileged by the trust our patients have in us and the personal nature of the discussions that we have with them. They often raise issues that we are not expecting and this book reminds us that we should be truly open in our consultations and look below the surface. We all make assumptions that are proved wrong and our perceptions are limited by our life experience to date. The real strength of this book for me, therefore, was not purely the story line but my reactions and feelings towards the events as they unfolded and the stark reminder that all is not what it seems. It made me think about the characters, trying to look at the world through their eyes and wonder, if this wasn't fiction, what had happened in their lives to make them behave as they do.

Reviewed by Janet Michaelis

Associate Specialist in Sexual and Reproductive Health, Worthing, UK

J Fam Plann Reprod Health Care 2011:37:117. doi:10.1136/fprhc.2011.0066 